\title{
It's common sense, stupid! Corporate crime and techniques of neutralization in the automobile industry
}

\author{
David Whyte ${ }^{1}$
}

Published online: 11 June 2016

C The Author(s) 2016. This article is published with open access at Springerlink.com

\begin{abstract}
This paper evaluates the usefulness of 'techniques of neutralization' and 'denial' theory for understanding how corporations respond to accusations of wrongdoing and criminal behaviour. It does so with reference to three recent cases in the automobile industry that have each been the subject of extended public outrage and regulatory response (the case of the Fiat Chrysler exploding Jeeps, the Toyota recall following a series of 'uncontrollable acceleration' incidents and Volkswagen's emissions fraud). The paper shows how in each of those systematic cases, corporate strategies were based upon the systematic deception of the public and systematic attempts to resist any recall to safeguard consumers. It then uses those cases as a focus of analysis for reframing 'techniques of neutralization' theory in a form that takes account of the immense social, economic and political power held by corporations and foregrounding the hegemonic role played by corporations in shaping 'common sense' understandings of the world.
\end{abstract}

\section{Introduction}

This paper evaluates the usefulness of 'techniques of neutralization' and 'denial' theory for understanding how corporations respond to accusations of wrong-doing and criminal behaviour. It does so with reference to three recent cases in the automobile industry that have each been the subject of extended public outrage and regulatory response. All of those cases emerged as major public issues, and were the subject of large-scale product recalls first in the US, before those recalls spread across the world. The paper uses those cases as a focus of analysis for reframing 'techniques of neutralization' theory in a form that takes account of the immense social, economic and political power held by

David Whyte

whyted@liverpool.ac.uk

1 Department of Sociology, Social Policy and Criminology, University of Liverpool, Eleanor Rathbone Building, Street South L69 7ZA, Bedford, UK 
corporations. It does so by analyzing the hegemonic role played by corporations in influencing our 'common sense' understandings of the world.

\section{Milton Friedman and the violence of corporate deception}

In the wake of the Ford Pinto case - a case that has for the past 40 years been used as a key reference point for 'corporate social responsibility' debates (see, for example, [1, 2]) - the hugely influential neo-liberal economist Milton Friedman made a remarkable statement in defence of Ford. The statement was made at televised question and answer session with economics students ${ }^{1}$ in which the key aspects of the case were set out: that following testing, Ford was aware of acute dangers of exploding fuel tanks in rear end collisions with their new model; Ford then used a series of calculations (balancing the value of any potential damages and injuries against the cost of a recall) to reach the conclusion that the car would be profitable if 180 people or less died in read end collisions [3]. Ford continued to sell the car, refusing to recall for 7 years after it was put on the market, with total estimates of Pinto-related deaths in that period perhaps three times the number of the original cost-benefit fatality estimates.

Consistent with his theoretical approach to questions of regulation, Friedman set out a case for the corporation's decision based upon a market rationale. Using this rationale he argued that placing a decision on the value of car safety should not be a matter for the public — since the 'public' were not part of the original transaction. The value of car safety was one that should be left to the parties directly involved in the purchase and use of the car.

A close reading of his argument in this televised debate reveals at least two major points that Friedman uses to justify his view. First, if we were given some role in this decision, it would mean we would make choices with unintended consequences. The costs generated by decisions made outside the immediate transaction could have any number of knock-on costs. Applying such a logic in extremis, then, he asks, what would be the limits of such decisions? The rhetorical answer to his rhetorical question is simply that the limits of such decisions are unbounded. Thus, "a million people should not starve to make a car that is absolutely safe". Second, and following the first point, he argues that the consumer must be free to decide whether to prioritise safety over cost. Government interference is not desirable (beyond the provision of basic law enforcement and court adjudication mechanisms) because, as a price distorting mechanism, government regulation interferes with people freely deciding the value of their own life through market mechanisms.

Perhaps the most significant logical difficultly with those claims - and there are many-lies in the idea that the risks can be efficiently distributed through the choices made by rationale, calculating, individuals in the market place. This idea, as all of the key neo-liberal theorists acknowledge, is challenged by the principle of 'perfect knowledge'. Put simply, market rationales such as the one articulated by Milton Friedman depend upon the idea that individuals are able to draw upon their knowledge

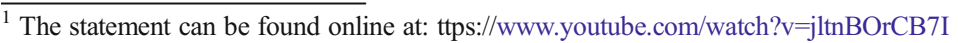


of a product in order to approximate the costs and benefits of buying a particular car. Thus, at one point in the debate, Friedman proclaims that:

You know when you buy a Pinto, that your chance of being killed is greater than your chance of being killed in a Mack truck....Everyone separately in this room, could, at a cost, reduce his risk of dying tomorrow.

Yet if the Ford Pinto case shows us one thing about the assumption of perfect knowledge, it is that in this case, the corporation was actively involved in preventing consumers from having the information required to make such a decision. Neo-liberals like Friedman do accept that the more incomplete or 'imperfect' knowledge about a product is, the more the transaction is distorted, but fail to recognize how central the power to distort is to market transactions. As every business and management text book shows, Ford was engaged in systematic deception. And as this paper will show, systematic deception is not unique to the automobile industry.

Close observers of other industries will not be surprised by the argument that is developed here. There is a large body of evidence that shows precisely the same process of deception in other industries: in tobacco, chemical and pharmaceuticals [4] in banking [5]; in mining [6]; in public utilities [7] and in energy particularly [8]. Put simply, a key source of corporate power found across those industries is the ability of corporations to deceive the public about the harmful effects of their products and their activities.

There is a body of literature that has sought to understand the mechanisms of deception in cases of white collar and corporate crime. This literature draws upon sociology of deviance theories of 'denial' and 'techniques of neutralization' to understanding how white collar and corporate crime is masked and how deceptions akin to those we have discussed in this opening section of the paper are perpetrated. It is this literature, a literature that is fundamentally concerned with studying how corporations and their executives justify the harmful effects of their business, that is briefly reviewed in the next section of the paper.

\section{Corporate techniques of neutralization}

The original perspective developed around concepts of 'techniques of neutralization' and 'denial' theory in the 1950s and 60s sought to explain how actors who engage in morally questionable or illegal activities justify their role in those activities. This perspective proposes that those who commit illegitimate acts or 'wrongdoing' engage in a process of neutralising certain values that might otherwise prevent them from committing those acts. The organising framework around which this perspective has developed was originally set out in the 1950s and 60s [9, 10]. Sykes and Matza's categories are set out as follows.

- Denial of responsibility (the wrongdoer was a victim of circumstance or was forced into a situation beyond her/his control).

- Denial of injury (her/his actions did not cause any harm or damage).

- Denial of the victim (the victim deserved whatever action the offender committed). 
- Condemnation of the condemners (those who condemn their wrongdoing are motivated by other, morally dubious reasons).

- Appeal to higher loyalties (the wrongdoing was committed was for the greater good, consequences that justify their actions).

In chapter 4 of his book, States of Denial, Cohen [11]) developed those categories and applied them to 'public and political atrocities', or human rights abuses, torture and state crimes. Cohen makes a key point to set up his analysis: that the accounts of denial disseminated by governmental and public bodies in official discourse are very similar to the accounts of denial offered up by individual personnel involved in those atrocities. As he points out: "The two sets of accounts will be similar. It cannot be otherwise" (ibid.: 76).

Following Cohen's linking of individual denial to organizational denial, there is good reason to expect that both corporate officials, and corporations, through corporate press statements and statement by CEOs on behalf of the corporation, use techniques of neutralization in dissociating their role in, and contribution to, a range of illegitimate activities and events. Indeed, a small body of research emerged in the 1980s to develop the concept of techniques of neutralization to corporate wrongdoing: the illegitimate activities that corporation engages in [12, 13, 14]. More recently there has been a resurgence of research that has applied this basic approach to corporate wrongdoing $([15,16,17]$; and [18]). This work uses precisely the same framework set out by Sykes and Matza and followed by Cohen (though remarkably, Cohen refers to none of this work on corporate denial in his work on state denial; 1993 and 2001).

First, corporate officials are well placed to deny responsibility. Box argues that they can do this by pleading: a) 'ignorance' (not knowing a criminal act took place, or not understanding). The complexity of the corporate structure readers knowledge of everything impossible that the structure of the corporation itself offers a basis for plausible deniability. Related to this is b) the 'bad apple' denial — where the behavior in question was caused by one or a small group of individuals that can be purged from the corporation to make it better again. The diffusion of responsibility through the structure of the corporations, in corporate crimes there is generally more than one person involved in the decision to act or not to act - make such denials of responsibility easy [15]; c) 'accident' (either there was no intent, or the circumstances were out with the control of the official, or even 'acts of God'); and d) 'acting under orders' (what Matza called 'natural reduction' or reducing one's own agency to the role of a cog in the machine with little or no power to prevent what happened).

Second, corporate officials are well placed to condemn the condemners, whether their condemners are workers, consumers, members of a local community, government regulators, or even members of other elites. The tendency towards worker blaming (or as Tombs [19] puts it "the accident prone worker") is well documented in industrial relations research. As Box [12]) notes, often the 'law' itself is condemned. The law may be claimed by perpetrators as unfair or unnecessary [14]. We find this claim, for example in the common recital by business organizations that the law is not 'flexible enough' or is ill-suited to the demands of modern business.

Third, corporate officials are well placed to deny the victim. This form of denial is aided by the apparently abstract nature of corporate victimization (ibid.). Often victimization takes place over a long period, making it unclear who caused the victimization. 
Again, this is partly a function of law: workers poisoned over a long period of time have historically found it difficult to attribute liability to their employer in tort cases. In this sense, often victims are ontologically or physically removed from the act or omission, or their victimization is mediated by other institutions or organizations [20, 21].

Fourth, corporate officials are well placed to deny harm or injury. For all of the reasons set out in the previous paragraph, given the conceptual leap required to identify victims (a leap that is we should not forget, not to do with the intrinsic qualities of corporate crime, but is almost entirely socially constructed) it is relatively easy to plausibly deny that any injury or harm actually happened. Very often this done is a tangential way, by sanitizing or re-defining the harm through a subtle use of language or re-positioning of concepts. This language might stress or draw attention to technical details (consumers were 'mis-sold' products rather than 'defrauded' or 'stolen from'). Denial of harm is also achieved simply because a lack of discussion of the injury or harm or a lack of available data prevents the problem being 'knowable'.

Fifth, corporate officials are well placed to appeal to higher loyalty and therefore neutralize the set of moral standards expected of them under law. Of course, the higher loyalty for corporate executives as set out in law is the fiduciary duty to shareholders to ensure the long-term success of the corporation. And often this fiduciary duty is invoked as a rationale for corporate crimes that sought to enhance the corporation's market position of profitability and so on [22]. Obeying the standards established by conventional business ethics generally, or in a particular sector might also be used to justifying not following legal standards. In this context, commonly corporate officials claim that business ethics are more socially important or even morally superior to legal standards. As part of such an appeal, Fooks et al. [18]: 286) identify a vaguely defined "expression of right" that uses as a reference point a set of (unspecified) universal rights that generally protect "business freedoms."

As this section has shown, we have a rich seam of research available to us which indicates that techniques of neutralization theory can be usefully applied to corporate crime. In order to explore the utility of this approach further, the paper will apply it to three cases from the automobile industry.

\section{Always crashing in the same car: three corporate scandals}

The case studies in this section were compiled by systematically analyzing three sources of information about the cases: investigative journalists reports published in US national newspapers, automobile industry publications and the press releases and public statements issued by companies themselves. For newspaper and journal data, keyword searches were conducted for the period 9th December 2006 to 9th December 2015 using Press Reader's international press database; press releases archives for each of the corporations Toyota, VW and Fiat Chrysler were also analyzed over this period as the principle source of public statements. The analysis was conducted using standard qualitative research techniques of framing to isolate key themes and identify the key messages being disseminated by those corporations at each of the key stages in the case identified in bullet points in each case below. 


\section{Fiat Chrysler's Exploding Jeeps}

From 2011 onwards it became apparent from media reports that there was a major issue emerging in relation to 1993-2004 Jeep Grand Cherokee and 2002-2007 Jeep Liberty vehicles manufactured by the Fiat Chrysler group. Indeed, by all accounts, the case bore a close resemblance to the Ford Pinto case discussed in the introduction to this paper. The following bullet points set out a summary of key events in this case.

- November 2011: the campaign group the Center for Auto Safety (CAS) issued a report on fuel tank fires caused when Fiat Chrysler Jeeps were involved in rear impact collisions. The CAS report claimed Jeeps had been involved in 185 fatal fire crashes involving 270 deaths and numerous burn injuries.

- April 2013: Fiat Chrysler Group refuses to comply with the NHTSA demand for a recall of 2.7 million vehicles

- January 2014: Fiat Chrysler agrees to a "fix" that involves fitting a tow hitch to the back of vehicles, rather than any substantial modification to fuel tanks.

- January 2015: The CAS notes that 1 million vehicles that were supposed to have been recalled remained unfixed, and that in this period at least 6 people have died in rear-end collision fires.

- March 2015: Fiat Chrysler CEO Sergio Marchionne issues a further statement insisting that Fiat Chrysler Jeeps are safe.

- April 2015: Houston Chronicle reports that only $4 \%$ of Jeep Grand Cherokees and $27 \%$ of Jeep Liberties have been repaired in the two years since the recall. In this period, it also claims, 57 people have died as a result of fuel tank explosions in Jeeps. Fiat Chrysler repeats the claim that "the vehicles do not pose an unreasonable risk to safety."

- July 2015: the NHTSA (National Highway Traffic Safety Authority, the principle auto safety regulator in the US) imposes a fine of $\$ 105 \mathrm{~m}(£ 67.6 \mathrm{~m})$ on Fiat Chrysler over recall failures. As part of the agreement, the corporation agrees to buy back 1.5 million vehicles, including the Jeeps subject to recall.

When Fiat Chrysler Group had refused to comply with the NHTSA demand for a recall in 2013, it was the first time since 1996 that an automobile manufacturer had done so. This case, over a problem with its seat belt system, also involved Fiat Chrysler. Indeed, in making this challenge, Fiat Chrysler Group had critiqued the methodology of the NHTSA's tests. Specifically it accused NHTSA of using "an incomplete and unrepresentative group of comparison vehicles, to determine its "peer group" and of failing to fully publish its data set.

Fiat Chrysler has continually denied that there are problems with its Jeeps. Indeed, throughout the case, the corporation repeatedly issued the following statement:

The subject vehicles are not defective and their fuel systems do not pose an unreasonable risk to motor vehicle safety in rear-impact collisions. ...Additionally, these vehicles met or exceeded all applicable federal motor vehicle safety standards in place at the time they were built.

Its denial is therefore largely based upon two claims. First, that the vehicles meet and exceed legal requirements. Indeed, the corporation cites its compliance with Federal 
Motor Vehicle Safety regulations on the standard of fuel systems. Second, it argues that the level of incidents is not abnormal: one would expect this level of fuel tank explosions in other vehicles produced and sold during the period that it had been forced to issue recalls for. In a major deviation from the other cases that will considered here, Fiat Chrysler has consistently used those arguments to issue aggressive public challenges to regulators. In condemning the methods used by the NHTSA, the corporation is able to present a technical challenge to the regulators demands upon it. This is more than simply 'condemning the condemners' but is a response that seeks to discredit the legitimacy and authority of the data upon which its decisions are based. Fiat Chrysler's public argument is quite simple: some people die as a result of collisions, and the rate of collisions experienced by Jeeps is not out of line for similar vehicles in that class in the US. In this context, the corporation has refused to respond directly to allegations that the number of deaths and injuries is widely recognised to be on a similar scale to the Ford Pinto case.

\section{Toyota's uncontrollable acceleration}

In 2009, a number of high profile cases were reported involving a problem with the accelerators on Toyota automobiles. ${ }^{2}$ Those cases were the subject of multiple major recalls involving a total of 20.5 million Toyota vehicles worldwide. The following bullet points set out a summary of key events in this case.

- September 2007: NHTSA orders recall of 55,000 for problems with "all-weather" floor mats apparently catching on pedals and causing uncontrolled acceleration.

- November 2009: 3.8 million vehicles are recalled for "pedal entrapment", said to have been caused by unsecured or stacked floor mats.

- January, 2010: 2.3 million vehicle recall for a "sticky gas pedal" problem which acknowledged a technical fault in the throttle (including 2.1 million vehicles already recalled for problems with floor mats); and an additional recall of 1.1 million vehicles on for "pedal entrapment problems."

- February 2011: recall of 2.2 million vehicles for "pedal entrapment"

One of the first cases which prompted the recalls occurred in August 2009 and involved the death of a driver and three members of his family after his Lexus crashed at over $100 \mathrm{mph}$ and burst into flames. The cause of the crash was determined as a faulty throttle which had stuck in the open position. A month after the full details of the case were revealed, Toyota released a customer safety advisory statement which concluded that floor mats can become entangled with the accelerator and cause it to stick. In this statement, Toyota advised drivers to people to remove the floor mats from their automobiles. A following recall two months later cited technical issues related to the throttle rather than problems with floor mats. Yet, at no point during the early recalls did Toyota answer to the evidence of "sudden acceleration" that was the subject of

\footnotetext{
${ }^{2}$ This is by no means the only recall case Toyota has been involved in since 2009. Other major recalls involve: February 2010 recall of Toyota Prius for brake failures; October 2014 recall of 1.75 million vehicles for brake failure; and October 2015: recall of 6.5 million vehicles to fix electric window switches that can short circuit and catch fire.
} 
numerous incidents and complaint (Washington Post 2010). The corporation opted to focus upon 'faulty floor mats' and 'sticky pedals'.

In a class action taken by Toyota owners over depreciation of the resale value of their automobiles, Toyota the corporation settled for a $\$ 1.6$ billion payout. And in a subsequent case taken by victims of a sudden acceleration incident in October 2013, the court found that unintended acceleration could have been caused due to deficiencies in the throttle system. In March 2014, following this ruling, Toyota entered into an out of court settlement with US regulators in which it agreed to pay a $\$ 1.2$ billion fine in order avoid prosecution for covering up the safety problems. The prosecution agreement included an admission which forced Toyota to accept that it "misled U.S. consumers by concealing and making deceptive statements about two safety related issues affecting its vehicles, each of which caused a type of unintended acceleration." NHTSA says Toyota knew about more fundamental accelerator problems in September 2009 but did not acknowledge the problem until January 2010. Toyota executives later admitted that they had to be "prodded" by the NHTSA to issue the January recall.

U.S. Attorney General at the time, Eric Holder, pointed out after the settlement was reached: "Toyota confronted this public safety emergency as if it was a public relations problem." The principle technique of neutralization used by Toyota was first, in the very early stages to engage in denial of the victim, and then develop what we might call 'technical' denials. First, the problem was blamed initially on driver error. Second, this denial was accompanied by the recognition that, if there was a flaw in the automobile design, it was a minor problem with floor mats - a less serious technical problem that of course does not necessarily require a refit-type recall, and only requires superficial remedy. Third, when it became clear that media exposures would undermine this explanation, the corporation cited "sticky gas pedal" as a cause. By doing so, the corporation carefully positioned the technical cause not as something integral to the electronics or to the mechanical design, but something that on the face of things sounds more anodyne and amenable to quick and easy resolution. It is this careful use of technical description that effectively enables a denial of the full implications of the fault. The Toyota strategy thus largely revolved around a two forms of denial based on highly 'technical' explanations.

\section{Volkswagen's emissions fraud}

In 2015, Volkswagen (VW) was at the centre of a major fraud scandal when it became publically known that the corporation had installed software that enabled its cars to cheat on emissions tests. The software detected when an automobile was on a test stand and switched to minimising nitrogen oxide emissions, but reverted to high emissions, and consequently, higher fuel efficiency when the car was driven normally. The following bullet points set out a summary of key events in this case.

- 2007: Bosch supplies software to Volkswagen in 2007 for internal testing only, warning that it was illegal install in cars on general

- May 2014: Researchers at the University of West Virginia find VW cars emitting up to 40 times as much nitrogen oxide than is legally permissible and alert US regulators.

- December 2014: VW recalls half a million cars in US for "software updates" and informs the EPA it has remedied the problem. 
- May 2015: The California Air Resources Board (Carb), undertake a new series of tests, the results of which are still unsatisfactory. Carb informs Volkswagen and the US Environmental Protection Agency (EPA).

- September 2015: VW eventually admits that 11 million vehicles worldwide are equipped with the defeat device software. The admission is limited, however to NO2 defeat devices in a relatively small number of diesel cars.

- November 2015: VW admit that defeat devices were also fitted to petrol engines and masked cheated $\mathrm{CO} 2$ emissions; and that defeat device software was installed in a much larger range of VW-owned brands than it previously admitted, including Porsche, Audi, SEAT and Skoda.

Four main denial strategies were employed by VW to mitigate the fallout of the scandal. First, in a similar strategy to that deployed by Toyota, there were a series of attempts to limit the number of vehicles included in the recall using language that portrayed the problem as a technical one that could be fixed through simple technical means. The statement that accompanied the admission that 11 million vehicles were affected noted a "deviation between bench test results and actual road use" and that "Volkswagen is working intensely to eliminate these deviations through technical measures." This focus on technical detail enabled VW to portray the nature of the problem as technical and to retail a central role in solving it (since it is only the corporation that has the technical capability to do so). Second, the corporation portrayed the case as a series of unintended mistakes, perhaps best portrayed by VW's US CEO (Michael Horn's statement that: "we have totally screwed up").This approach has continued. In December 2015, the new Chairman of the corporation Hans Dieter Poetsch made a major public statement in which he announced: "We are talking here not about a one-off mistake but a chain of errors."

Thus, the corporation positions its actions not as part of a deliberate strategy, but as more accidental "screwing up" or "errors". Third, those statements have been accompanied by a consistent denial of knowledge by the most senior managers in the corporation, denials that have become wholly implausible as the details of the various warnings issued to the corporation, and the level of its knowledge for at least 18 months prior to the scandal being made public. Even when he resigned on September 21st 2015, CEO Martin Winterkorn claimed he was "not aware of any wrongdoing on my part". Linked to thus, denial of responsibility has been claimed through a consistent attempt to blame a few "bad apples" (or, in Winterkorn's words "the terrible mistakes of a few people").

In November 2015, VW announced a two week amnesty for employees who came forward with information and guaranteed that it would "waive consequences under labour law such as the termination of employment, and will not make any claim for damages." Clearly this initiative focused the corporation's energies onto the potential culpability of workers rather than senior managers, fairly typical of the corporation's denial of responsibility strategy. Finally, the corporation regularly stressed its co-operation with regulators, thereby asserting the basic law-abiding nature of the corporation. The statement quoted in the previous paragraph included a nod to VW's law observance which is typical of those that the corporation has issued throughout the crisis: 
The company is... in contact with the relevant authorities and the German federal motor transport authority... Volkswagen does not tolerate any kind of violation of laws whatsoever.

Over time, the corporation has certainly become gradually more silent and less assured in issuing such denials. By the time the CO2 scandal emerged in November, despite the corporation issuing regular statements and new revelations, its senior officers had become remarkably un-candid and generally refused to admit any knowledge of say anything beyond the public statements issued by the corporation.

As the discussion here shows, in a number of respects, the various denials developed by the corporations and their senior officers in those three cases fit well with the Sykes and Matza framework. Yet in a number of respects they do not. As the next section will discuss, when we actually apply the framework to those cases it appears limited; Sykes and Matza's 5 categories do not quite capture the full spectrum of corporate denial (see also, [23]). As Cohen [24]) notes, the original Sykes and Matza argument acknowledges the disconnection of young peoples understandings of their world from political constructions of their world, or indeed the worlds of the powerful. And this is really our point of departure. The political and economic power enjoyed by corporations (as the key institutional structures that bring capital to life), and the senior managers that occupy positions at the very top of the social hierarchy, provides corporate denials with a social force and authority that cannot be rivaled by 'common' criminals. A major criticism of Sykes and Matza's original formulation is that it failed to acknowledge the way that particular social contexts shape both the act and the ideological context for the act. The following section therefore develops an understanding of how the forms of corporate denial that we observe in the 3 cases as being always connected to the structural power of corporations.

\section{Corporate techniques of neutralization}

In many ways, the point of Cohen's [11]) analysis of state denial is based an understanding of the cultural capital enjoyed by powerful institutions. Just as we find in the Cohen's analysis of state power, the culturally dominant position enjoyed by corporations, combined with the resources they can draw upon to employ public relations advocates, develop press and publicity strategies and so on, enables them to present a very wide range of 'truths' about their activities which allow them to render particular events or processes relatively invisible.

Fiat Chrysler's strategy of denial was on the face of things, despite the moment of exposure it faced, particularly belligerent and confident. The principle strategy employed by the corporation was to simply deny that the deaths and injuries occurred at a rate higher than one could normally expect in vehicles of a similar class. Second, Fiat Chrysler consistently maintained that it is compliant with Federal regulations, and stuck to this line even when the NHTSA showed a string of violations. This claim was always linked to an undermining of the integrity of the NHTSA's data. In this sense, we can see how this strategy is part of a very straight 'condemnation of the condemners' technique of neutralization. 
If the latter represents a straight fit with the Sykes and Matza framework, the first does not seem to fit so easily. The first form of denial represents something that we might call a 'denial of deviance'; a form of denial that projects the condemned behavior as the cultural norm. The exploding Jeeps are not something that need to be justified since the rate of incidents is not outside the normal expectations in the industry, society and so it. In this respect, Coleman [14]) identifies a closely related 'everybody's doing it' rationale in which corporate officers point to the culture of the industry. He recalls one respondent in Cressey's study of embezzlers:

We did a little juggling and moving around, but everyone in the real estate business has to do that. We didn't do anything that they all don't do ([25]: 137, cited in ibid.: 413).

This type of raionale begins to locate the event or process or behavior in a 'normal' structure of business. It is a rationale that is powerful because of its invoking of what is normal cultural practice and therefore cannot be deviant. Part of this is an explicit denial of deviance - the conduct under discussion does not deviate from normal industry practice. This is a form of denial that was not treated as distinct category in Sykes and Matza although it might be argued that this is in any case implied in their sub-cultural approach to deviance. Yet the ability to deny deviance is especially relevant for corporations since they can make claims that have a social credibility that young people or common criminals generally do not have.

As the previous section noted, the form that denial took in the Toyota case was shaped by a similar ability to define what it had done as not abnormal or deviance in technical industry terms. In the sense that the seriousness of the consequences of the flaw in the vehicle was talked down by Toyota's technical explanation this is close to Sykes and Matza's category of 'denial of harm'. But this is not quite the same as denying harm. It is denying the seriousness of the risk through a technical repositioning of the problem. It is better described as denial of cause. In order to deny the cause of the problem, it helps to have some control or influence over the cause of the problem. In this case, the technical cause of the problem rests somewhere in Toyota's system of development and production; it lies somewhere in the organization. Of course, in the case of problems that are produced in organizations, we can be sure that the cause lies somewhere in the organization.

To some extent, Toyota's 'denial of cause' was given widespread support from key industry publications. For example, number 1 automobile industry publication Car and Driver [26]: 1) pronounced that the regulatory response to the case represented a "good, old-fashioned government freakout" and number 2 publication Motor Trend railed in its editorial at the height of the crisis: "we're all in way more danger of being killed by a drunk driver than a careering Toyota." ([27]: 1) In this sense, the technical denial issued by Toyota was given both credibility and, crucially, was disseminated to key audiences by this section of the media. However, this support from within the industry, although providing a significant antidote to a series of highly critical ABC News broadcasts, did not neutralize the general media coverage of the case. As The Atlantic noted, from "January 2010 through February 2010, as Toyota recalls mounted and as Congress held hearings, Toyota recall coverage ranked, in all but one week, among the top ten news stories across all media. This was an extraordinary amount of news coverage" ([28], p. 21-22). 
The climate that enabled Toyota to be exposed in this way was certainly made worse for the corporation given the evidence that political support for Toyota was not particularly strong. It is possible that Japanese brands such as Toyota do not enjoy the same access to politics or political support that US automobile brands such as GM or Ford do. Thus, major political figures did make very strong statements against the corporation. At the high point of the recalls, in February 2010, the US Transportation Secretary Ray LaHood urged the public to stop driving their Toyotas immediately. It is this political mood that the case developed in that helps us to understand why Toyota continued to fall back on a form of denial that it could retain some control over: a technical denial of cause.

The same point might be said for VW as a foreign car manufacturer. Yet there is little evidence of a concerted political attack on the corporation. VW therefore had the space to develop a denial of responsibility (the fraudulent practices equated a series of unintended mistakes that the corporation got caught up in), but also in stressing the exemplary record of the corporation, and in particular its law abiding nature, VW sought to represent what had happened as highly unusual for an otherwise scrupulous corporation. In other contexts, this has been called the 'ledger technique' [18, 29] and is illustrated well by Benson's [13]) tax evaders, who portrayed their crimes as an uncharacteristic flaw in their otherwise unblemished record. As Benson (ibid.: 599) notes, for labeling of white-collar criminals to be successful, the criminal event or practice must be shown to be out of the ordinary, or "revealed as obviously and unquestionably profane" and at the same time must be "indicative of a pattern of behavior that is the opposite of that expected of the normal citizen." To paraphrase Benson, the denial of deviance and denial of the norm aim to reveal corporate crime either as indicative of a pattern of behavior, but not unquestionably profane (how can it be, if everyone does it?) or unquestionably profane but not part of a general pattern of behavior.

In two of the cases, we find that the primary strategies of denial described here were always accompanied by clear public statements about the social contribution of the corporation (job creation, investment in the local economy and so on) or about the high quality of the product and the high consumer regard for the corporation's automobiles. Thus, the joint Toyota press statement that was released when its $\$ 1.2$ billion fine was announced by the US Department of Justice noted:

over the past 50 years, we've built more than 25 million cars and trucks in North America, where we operate 14 manufacturing plants (10 in the US) and directly employ more than 42,000 people (more than 32,000 in the US)....Toyota partners with philanthropic organizations across the country, with a focus on education, safety and the environment ([30]: 1).

VW has similarly accompanied public statements on the defeat device scandal. For example in a key statement as part of his testimony to the House Committee of Energy and Commerce, Michael Horn pointed out:

Volkswagen Group has a deep commitment to preserving our environment...For example here in the United States, Volkswagen's manufacturing facility in Chattanooga, Tennessee...received a platinum certification from the US Green 
Building Council's Leadership in Energy and Environmental Design programme...the first and only automobile manufacturing plant in the world to receive a platinum award... That factory alone employs more than 2,200 people and is expanding (VW Press Release, October 8th, 2015).

Fiat Chrysler did not tend to push such 'social contribution' assertions to the fore, probably because the type of denial it engaged in was different. Clearly the most belligerent corporation in any of the cases, Fiat Chrysler did not accept responsibility right up until it was handed a multi-million dollar fine in July 2015. Following this point, its strategy changed to appeasing the regulator and concentrated on addressing issues of internal organization (for example, by appointing a new compliance officer reporting directly to the $\mathrm{CEO}$ ).

The statements of the type made by Toyota and VW, which are fed constantly, in drip-drip fashion, as part of the corporate public relations strategy, represent a technique of neutralization that is close to, but is not quite covered by "appeal to higher loyalties". Yet, there is a higher purpose being noted here, and this higher purpose is that of the social or economic contribution made by the corporation. But it is not exactly an appeal to anything specific, or anything that loyalty could be generated around. It is more a general appeal to social benefit. Indeed, this is an observation made previously by Coleman [14]) who notes that when an offence is committed by white-collar criminals, it is very often legitimised by the social benefits that will accrued from the survival or long term success of the corporation. The survival of the corporation may be important either to ensure that an employee keeps her job, or to ensure that the business stays competitive and therefore is able to survive in a tough market place (see also $[15,31]$ in [18]). Of course, this justification is often linked to a series of normative spin-offs: that economic development and growth will be secured, than the business's contribution to the community will be preserved and so on. In other words, not committing an offence in those circumstances might have exposed a corporate officer to moral censure. This is more than simply an appeal to higher loyalties because the corporation is laying claim to the status of its contribution to society as essential.

In sum, the analysis of those cases of corporate denial presented here have so far shown that we cannot disaggregate the techniques of denial used by corporate criminals from the power structures that corporations are part of. We therefore cannot understand corporate denial without understanding how they are shaped by the power and privileges that corporations enjoy in capitalist societies more generally, and, crucially, by the dominant social position that allows corporations to plausibly assert the social benefits of their role as employers, investors in the community, wealth creators and so on.

\section{Its common sense, stupid!}

The social fabric of corporate power and political influence that stands behind and gives force to strategies of denial is therefore a crucial starting point. Yet it is a point that generally absent from the body of research on techniques of neutralization and corporate crime that is reviewed here. In one notable exception, Coleman [14]) argues that techniques of neutralization are always somehow connected to a much broader sets of claims and understandings of the world. And those claims and understandings exist 
in public discourse prior to the dissemination of corporate statements and denial strategies. Here, a Gramscian concept of common sense is important for understanding the wider sets of ideas and propoganda claims that always stand somewhere behind corporate denials [32]. From a Gramscian perspective, particular ideas and particular ways of interpreting the world (or 'common sense') are promoted and disseminated by elites as part of an ongoing process of securing hegemony. The successful dissemination of common sense is crucial to elites in providing popular consent for particular strategies of rule. Common sense claims always invoke or grow out of 'real' material practices, but they also tend to project claims about the social order that are ultimately fabricated or 'imaginary' rather than purely projecting the observable or the real, experienced, order of the social world. It is the 'common sense' ideas that we hold to be true about corporations and the world they inhabit that give the force of credibility to corporate denials.

So, what are the common sense claims that stand behind, and give force to corporate denials in the automobile industry? First, we might observe that Fiat Chrysler's denial of deviance is given force by a complex and longstanding set of common sense ideas that assert corporate crime is not 'real crime' $[33,20]$. There is a long history of the parallel development of the criminal law and the corporation that explains how this came about [34]. But without entering into this discussion, it is enough to note that the common sense understanding of corporate crime as 'not real crime' is reinforced by an expansive architecture of criminal laws, criminal justice agencies and associated institutions. This architecture not only enables corporate crime to be defined as something different from conventional crime, but also erects a complex set of rules and practices that effectively excludes corporations from criminal responsibility (ibid.). Thus, when Fiat Chrysler says claims it does is not abnormal, and certainly not criminal, then this has some social force. Similarly, when a major household name corporation like VW asserts that it is law abiding, this assertion has a substantial weight of social acceptance and legal practice to support it.

Second, Toyota and VW assertions of their social contribution are based upon a broader set of claims that corporations are structures that are socially beneficial. The range of social benefits that corporations are economically efficient (which reduces social costs and therefore brings benefits to consumers); are innovative (meaning that they are capable of delivering technological advances that benefit us all); job creation and investment in communities (which brings long-term benefits of the development of infrastructure, the spin off economic benefits that occur when companies re-locate and so on). Those are things we all hold to be true about corporations, regardless of the evidence that contradicts such claims to efficiency and innovation [35]. However, it is the enduring permanence of such claims that enables companies such as Toyota and VW to seek to mitigate their crimes. If they made mistakes in relation to the cases we examined here, then this should not compromise their position as major contributors to society. This certainly marks them out as a different class of offenders. How many 'common criminals' can claim that their victimization by state regulation or punitive intervention could compromise the social fabric of the nation?

The observations set out in this section have been highly selective in analysing what we might call first and second order normative justifications for what corporations do and how they do it. Having said this, Table 1 below summarises the key first and second order normative justifications discussed in this section. The table is 
Table 1 First and second order justifications

First Order (common sense)

Corporations provide essential social benefits

Differentiation of corporate/white collar crime from inter-personal crime
Second Order (corporate denial)

'Social benefit' denial (VW and Toyota)

'Denial of deviance' (VW and Fiat Chrysler)

indicative rather than exhaustive; it merely offers the initial steps of an approach to analysing the social power that stands behind corporate denials. The purpose of this quick analysis is therefore merely to illustrate how there is generally a connection between first and second order justifications: the first order justifications at the level of common sense, and second order justifications at the level of 'denial' or 'techniques of neutralization'.

\section{Conclusion}

By using the structurally dominant position they enjoy, corporations are empowered by their ability to conceal basic facts about the safety of their products, the true costs of production and so on. As we saw at the beginning of this paper, Milton Friedman's analysis of the Ford Pinto masked the fundamental deception that corporations much engage in. Indeed, it is important to observe not simply that corporations deceive the public and cover up the violent consequences of their decisions, but in many mays this is a necessary condition of their success. After all, Ford's aggressive no-compromise approach to marketing the Pinto as an affordable (if deadly) compact car was largely due the threat to its market share at the time posed by Volkswagen and the Japanese manufacturers [3]. The three cases that we have discussed in this paper are only three amongst a multitude of major car safety scandals over the past decade or so. This perpetual crisis in car safety is itself a product of the intensity with which the major manufacturers seek to dominate market share. The routine deception that has been analysed here is similarly a product of ongoing wars for market share.

This is not to say that the problem of corporate denial is simply a condition of the market; it is also a condition of government. Toyota, Fiat Chrysler or VW are market players whose right to deceive is careful protected by governments (in the cases we have explored, the US government). Nothing, not the negligent and avoidable killing of consumers, nor even their contribution to the ultimate human catastrophe-global warming - is allowed to get in the way of the inalienable right of automobile corporations to accumulate profits.

All of this leads us to a relatively simple conclusion: in order to challenge denial, it is not enough merely to win the argument — or even make a 'choice'-based upon the information that we have available to us. Neither it is enough to show that corporate activities are of themselves fundamentally deceptive. In order to challenge the force of credibility behind corporate denials we must also challenge the source of hegemonic corporate power. This means challenging the mechanisms that guarantee the social dominance of corporations and not merely the spurious knowledge claims that re- 
produce their social dominance. Ultimately this means seeking ways of abolishing the legal, political and social foundations upon which corporate power rests.

Acknowledgments I am grateful to the anonymous reviewers of this article for their suggestions and insights. Earlier versions of this paper were presented at the KTH in Stockholm, the University of Victoria and the University of Melbourne in 2015, and the discussions and feedback from participants at those meetings were crucial in developing the arguments here. In particular my thanks go to Annie Delaney, Vania Ceccato and Jennifer Balint for hosting those meetings.

Open Access This article is distributed under the terms of the Creative Commons Attribution 4.0 International License (http://creativecommons.org/licenses/by/4.0/), which permits unrestricted use, distribution, and reproduction in any medium, provided you give appropriate credit to the original author(s) and the source, provide a link to the Creative Commons license, and indicate if changes were made.

\section{References}

1. Birsch, D., \& Fielder, J. (1994). The Ford Pinto case: A study in applied ethics. New York: State University of New York Press.

2. Shaw, W. (2011). Business ethics: A textbook with cases (7th ed.). Boston, MA: Wadsworth.

3. Dowie, M. (1977). Pinto madness. September/October: Mother Jones.

4. Michaels, D. (2008). Doubt is their product: How industry's assault on science threatens your health. Oxford: Oxford University Press.

5. Platt, S. (2015). Criminal capital: How the finance industry facilitates crime. London: Palgrave.

6. Kirsch, S. (2014). Mining Capitalism: The relationship between corporations and their critics. Berkeley: University of California Press.

7. Meek, J. (2014). Private island: Why Britain now belongs to someone else. London: Verso.

8. Oreskes, N., \& Conway, E. (2012). Merchants of doubt: How a handful of scientists obscured the truth on issues from tobacco smoke to global warming. New York: Bloomsbury.

9. Matza, D. (1964). Delinquency and drift. New York: Wiley.

10. Sykes, G., \& Matza, D. (1957). Techniques of neutralization: a theory of delinquency. American Sociological Review, 22, 664-670.

11. Cohen, S. (2001). States of denial. Knowing about atrocities and suffering. Cambridge: Polity Press.

12. Box, S. (1983). Power, crime and mystification. London: Sage.

13. Benson, M. (1985). Denying the guilty mind: accounting for involvement in a white-collar crime. Criminology, 23, 583-607.

14. Coleman, J. (1987). Toward an integrated theory of white-collar crime. American Journal of Sociology, 93(2), 406-439.

15. Heath, J. (2008). Business ethics and moral motivation: a criminological perspective. Journal of Business Ethics, 83, 595-614.

16. Piquero, N., Tibbetts, S., \& Blankenship, M. (2005). Examining the role of differential association and techniques of neutralization in explaining corporate crime. Deviant Behavior, 26(2), 159-188.

17. Vieraitis, M., Piquero, N., Piquero, A., Tibbetts, S., \& Blankenship, M. (2012). Do women and men differ in their neutralizations of corporate crime. Criminal Justice Review, 37(4), 478-493.

18. Fooks, G., Gilmore, A., Collin, J., Holden, C., \& Lee, K. (2013). The limits of corporate social responsibility: techniques of neutralization, stakeholder management and political CSR. Journal of Business Ethics, 112, 283-299.

19. Tombs, S. (1991). Injury and ill-health in the chemical industry: Decentring the accident-prone victim. Organization and Environment, 5(1), 59-74.

20. Slapper, G., \& Tombs, S. (1999). Corporate crime. London: Longman.

21. Whyte, D. (2007). Victims of corporate crime. In S. Walklate (Ed.), A handbook of Victimology. Willan: Collumpton, Devon.

22. Clinard, M., \& Yeager, P. (1980). Corporate crime. New York: Free Press.

23. Whyte, D. (2012). Between crime and doxa: researching the worlds of state-corporate elites. State Crime, $1(1), 88-108$. 
24. Cohen, S. (1993). Human rights and crimes of the state: the culture of denial. Australian and New Zealand Journal of Criminology, 26(2), 97-115.

25. Cressey, D. (1953). Other people's money: A study of the social psychology of embezzlement. Glencoe: The Free Press.

26. Car and Driver (2010). Toyota recall timeline: What went down when. Car and Driver, 2 April 2010, http://blog.caranddriver.com/toyota-recall-timeline-what-went-down-when/. Accessed 4 April, 2016.

27. MacKenzie, A. (2010). The toyota recalls, 1 March 2010, http://www.motortrend.com/news/the-toyotarecalls-blood-on-the-hill-2610/, Accessed 4 April, 2016.

28. Cole, R (2011). Who was really at fault for the Toyota recalls? The Atlantic, 1 May 2011, http://www. theatlantic.com/business/archive/2011/05/who-was-really-at-fault-for-the-toyota-recalls/238076/. Accessed 14 April 2016.

29. Moore, R., \& McMullan, E. (2009). Neutralizations and rationalizations of digital piracy: a qualitative analysis of university students. International Journal of Cyber Criminology, 3(1), 441-451.

30. Bruce, C. (2014). Toyota reaches $\$ 1.2 \mathrm{~B}$ unintended acceleration settlement in criminal probe, Autoblog, March 19th, http://www.autoblog.com/2014/03/19/toyota-1.2-billion-unintended-acceleration-criminalprobe-settlement. Accessed 4 April 2016.

31. Minor, W. W. (1981). Techniques of neutralization: a reconceptualization and empirical examination. Journal of Research in Crime and Delinquency, 18(2), 295-318.

32. Gramsci, A. (1996). Selections from the prison notebooks. London: Lawrence and Wishart.

33. Friedrichs, D. (2010). Trusted criminals: White-collar crime in contemporary society (4th ed.). Belmont, CA: Wadsworth.

34. Tombs, S., \& Whyte, D. (2015). The corporate criminal. London: Routledge.

35. Whyte, D. (2015). The mythology of business. Liverpool: Institute of Employment Rights. 